\title{
Regulatory effect of cytokine-induced neutrophil chemoattractant, epithelial neutrophil-activating peptide 78 and pyrrolidine dithiocarbamate on pulmonary neutrophil aggregation mediated by nuclear factor- $\kappa B$ in lipopolysaccharide-induced acute respiratory distress syndrome mice
}

\author{
HONGMAN WANG ${ }^{1-3}$, JIPING ZHAO ${ }^{3}$, GUANSHENG XUE ${ }^{4}$, JUNFEI WANG ${ }^{3}$, \\ JINXIANG WU ${ }^{3}$, DONGHUI WANG ${ }^{1}$ and LIANG DONG ${ }^{3}$
}

\begin{abstract}
${ }^{1}$ Department of Pulmonary Medicine, The Third Affiliated Hospital of Liaoning Medical University, Jinzhou, Liaoning 121001; ${ }^{2}$ Department of Pulmonary Medicine, The Fifth Affiliated Hospital of Zunyi Medical University, Zhuhai, Guangdong 519100; ${ }^{3}$ Department of Pulmonary Medicine, Qilu Hospital of Shandong University, Jinan, Shandong 250012; ${ }^{4}$ Department of Thoracic Surgery, 205 Hospital of Chinese People's Liberation Army, Jinzhou, Liaoning 121001, P.R. China
\end{abstract}

Received June 2, 2015; Accepted January 15, 2016

DOI: $10.3892 /$ etm.2016.3520

\begin{abstract}
In the present study, the regulatory effect of cytokine-induced neutrophil chemoattractant (CINC) and epithelial neutrophil-activating peptide 78 (ENA-78) on pulmonary neutrophil (PMN) accumulation in lipopolysaccharide (LPS)-induced acute respiratory distress syndrome (ARDS) mice, and the therapeutic effect of pyrrolidine dithiocarbamate (PDTC), was investigated. BALB/c mice were divided into control, LPS and PDTC + LPS groups using a random number table. The phosphorylation of nuclear factor- $\kappa \mathrm{B}(\mathrm{NF}-\kappa \mathrm{B})$ was detected using a western blot, and the mRNA expression levels of CINC were evaluated using reverse transcription-quantitative polymerase chain reaction. The expression of NF- $\kappa \mathrm{B}, \mathrm{CINC}$ and ENA-78 was detected using immunohistochemistry. The production of interleukin (IL)-8 and IL-10 in serum and broncho-alveolar lavage fluid (BALF) was analyzed using an enzyme-linked immunosorbent assay. The total number of leukocytes and proportion of PMNs in BALF was also determined. Following injection with LPS $(20 \mathrm{mg} / \mathrm{kg})$, the expression levels of $\mathrm{p}-\mathrm{NF}-\kappa \mathrm{B}, \mathrm{CINC}$ and ENA-78 were increased in lung tissue, and the expression levels of IL-8, IL-10 and the number of PMNs increased in
\end{abstract}

Correspondence to: Professor Liang Dong, Department of Pulmonary Medicine, Qilu Hospital of Shandong University, 107 Wenhua Xi Road, Jinan, Shandong 250012, P.R. China E-mail: d15506@126.com

Key words: nuclear factor- $\kappa \mathrm{B}$, acute respiratory distress syndrome, polymorphonuclear neutrophils, cytokine-induced neutrophil chemoattractant, epithelial neutrophil-activating peptide 78 serum and BALF. However, in comparison with the LPS group, the degree of lung injury was reduced in ARDS mice that were treated with PDTC. In addition, the expression level of $\mathrm{p}-\mathrm{NF}-\kappa \mathrm{B}$ and the production of chemokines in lung tissue decreased in ARDS mice that were treated with PDTC, and the number of PMNs in BALF also decreased. In conclusion, the results of the present study suggest that the LPS-induced phosphorylation of $\mathrm{NF}-\kappa \mathrm{B}$ may result in the synthesis and release of CINC and ENA-78, which induce the accumulation of PMNs in the lung. Therefore, PDTC may be used to reduce the production of chemokines and cytokines, thereby decreasing the activation of PMNs in lung tissue and reducing the damage of lung tissue in ARDS.

\section{Introduction}

Acute respiratory distress syndrome (ARDS) is a common and severe lung disease that is associated with high rates of mortality and morbidity, and leads to reduced levels of oxygen in the blood $(1,2)$. The characteristic features of ARDS include excessively uncontrolled inflammation, hypoxemia and non-cardiogenic pulmonary edema formation (3). These are caused by various increased inflammatory cytokines and pulmonary microvascular permeability (4).

The main sites of cell injury in ARDS are the vascular endothelium and alveolar epithelium (4). Polymorphonuclear neutrophils (PMNs) contribute towards lung inflammation and serve important roles in the pathogenesis and progression of ARDS (3). Lung injures may result in the infiltration and activation of PMNs, involving a complex process including the recruitment, adhesion and chemotaxis of PMNs $(3,4)$. Bhatia and Moochhala (5) have demonstrated that a large number of PMNs can accumulate in lung tissue and release inflammatory cytokines, such as interleukin (IL)-8, IL-10 and tumor necrosis factor-alpha (TNF- $\alpha$ ), 
which serve important roles in activating and maintaining the inflammatory response (6). IL-8 and the epithelial neutrophil activating peptide (ENA-78) are critical for the accumulation of PMNs in lung tissue (7); the expression of adhesion molecules on the surface of PMNs increases with appearance of these chemokines (5). Adhesion molecules and their ligands provide a strong adhesion between PMNs and endothelial cells, allowing PMNs to migrate to the vessel wall $(8,9)$. Cytokine-induced neutrophil chemoattractant (CINC), a member of the IL-8 family, is a specific PMN chemokine that serves a crucial function in the aggregation of PMNs in lung tissue $(10,11)$.

Nuclear factor- $\mathrm{KB}(\mathrm{NF}-\kappa \mathrm{B})$ is a critical nuclear transcription factor, able to activate the transcription of a number of inflammatory cytokine genes and regulate the inflammatory response and immunoreaction (12). Typically, NF-kB exists as an inactive dimer in the cytoplasm and directly combines with an inhibitor of nuclear-factor $\kappa \mathrm{B}(\mathrm{I} \kappa \mathrm{B})$ to produce a trimeric complex (13). The P50/P65 heterodimer serves an important physiological function during inflammation, and NF-кB P65 is the principal subunit (14).

Lipopolysaccharide (LPS) is the main component of gram-negative bacteria outer membranes, which is a common trigger of sepsis, and is the initiation factor that activates the NF- $\kappa B$ signaling pathway (15). Phosphorylated (p)-NF- $\kappa B$ can enter into the nucleus and bind to specific DNA sequences when stimulated by LPS (15). The activation of NF- $\kappa B$ is closely associated with the overexpression of adhesion molecules, chemokines and other cytokines involved in the migration of PMNs, and therefore serves an important role in the regulation of inflammation and ARDS (16). However, IL-10 is a principal anti-inflammatory cytokine and can inhibit the activation of NF- $\mathrm{KB}$ (17).

Pyrrolidine dithiocarbamate (PDTC), an inhibitor of $\mathrm{NF}-\mathrm{KB}$, has been reported to inhibit the expression of inflammatory cytokines, such as ILs and TNF- $\alpha$, at the stage of transcription (18). In addition, PDTC reduces the expression of chemokines, such as CINC and ENA-78, and the accumulation of inflammatory cells in lung tissue in order to alleviate the pathological changes in the lung tissue of ARDS $(11,19)$. It is therefore important to reduce the expression of CINC and ENA-78, and the accumulation of PMNs in lung tissue, by regulating NF- $\kappa B$ phosphorylation and hindering NF- $\kappa B$ activation. The present study aimed to investigate the regulatory effect of CINC and ENA-78 on PMN aggregation mediated by NF- $\mathrm{KB}$, and the direct protective effects of PDTC on lung tissue in LPS-induced ARDS mice.

\section{Materials and methods}

Animals. A total of $90 \mathrm{BALB} / \mathrm{c}$ mice (age, 8-10 weeks; weight, $20 \pm 2 \mathrm{~g}$ ) were purchased from the Experimental Animal Center of Shandong University (Jinan, China) and housed at room temperature $\left(24^{\circ} \mathrm{C}\right)$ with a 12 -h light/dark cycle. The mice were allowed free access to water and standard laboratory chow. The experimental procedures were approved by the Ethics Review Committee for Animal Studies at Qilu Hospital, Shandong University (Jinan, China) and performed in accordance with animal welfare and animal experimental guidelines.
Mice received an intraperitoneal (i.p.) injection of $20 \mathrm{mg} / \mathrm{kg}$ LPS (Escherichia coli O55:B5; Sigma-Aldrich, St. Louis, MO, USA) and an i.p. injection of PDTC $(0,40$, 120 or $160 \mathrm{mg} / \mathrm{kg}$; L04358; USA Alikesi International Group (China), Ltd.). PDTC (Beyotime Institute of Biotechnology, Haimen, China) was administered $30 \mathrm{~min}$ prior the injection of LPS.

To further investigate the protective effect of PDTC on LPS-induced ARDS mice, 90 mice were randomly divided into three groups ( $n=30 /$ group), as previously described (20): Control (20 ml/kg normal saline, i.p.); LPS (20 mg/kg, i.p.); and PDTC (120 mg/kg, i.p) + LPS (20 mg/kg, i.p.).

Specimen collection. Blood, lung tissue and bronchoalveolar lavage fluid (BALF) samples from each group of mice were collected simultaneously after modeling for 2, 6, 12 or $24 \mathrm{~h}$. The mice were anesthetized by intraperitoneal injection with $10 \%$ chloral hydrate $(3.5 \mathrm{ml} / \mathrm{kg}$; Sigma-Aldrich), prior to sacrifice via aortic phlebotomy at the indicated time points. Subsequently, the lungs were extracted and the left lung was prepared for hematoxylin and eosin (HE) staining (Beyotime Institute of Biotechnology) and immunohistochemistry, while the right lung was prepared for western blot analysis. PMNs were isolated from BALF using Wright-Giemsa staining (Beijing Leagene Biotech, Co., Ltd., Beijing, China). After centrifugation at $1,200 \mathrm{xg}$ for $10 \mathrm{~min}$ at $4^{\circ} \mathrm{C}$, the supernatant was collected and the expression of IL- 8 and IL-10 was detected using enzyme-linked immunosorbent assay (ELISA) kits. Specifically, the expression of IL-8 was detected using the Quantikine ELISA kit from R\&D Systems Europe, Ltd. (Abingdon, UK), whereas the expression of IL-10 was detected using the LEGEND MAX ${ }^{\mathrm{TM}}$ Mouse IL-10 ELISA kit from BioLegend, Inc. (San Diego, CA, USA).

Histopathological analysis. The left lung was fixed with $4 \%$ paraformaldehyde (Beijing CellChip Biotechnology, Co., Ltd., Beijing, China) for $24 \mathrm{~h}$, embedded in paraffin and cut into $4 \mu \mathrm{m}$ sections. Once stained with hematoxylin and eosin, an evaluation was performed to characterize the degree of lung injury. Briefly, the lung injury score was calculated by assessing the degree of inflammatory cell infiltration, hemorrhage, interstitial and alveolar edema and the thickness of the alveolar septum in five random fields in a blind manner using a light microscope (Olympus BX43; Olympus Corportation, Tokyo, Japan).

Determination of the difference between alveolar and arterial oxygen partial pressure $\left.\left[P(A-a) O_{2}\right)\right] . \mathrm{PaO}_{2}$ and $\mathrm{PaCO}_{2}$ were analyzed in $150-\mu 1$ arterial blood samples and the oxygen partial pressure (alveolar oxygen partial pressure) was calculated according to the results of a blood gas analysis: $\mathrm{PaO}_{2}=($ atmospheric pressure -47$) \times \mathrm{FiO}_{2}-\mathrm{PaCO}_{2} / \mathrm{R}$ $(\mathrm{R}$, the exchange rate; $\mathrm{R}=0.8)$. Alveolar - arterial oxygen partial pressure difference (A-a) $\mathrm{O}_{2}=$ (atmospheric pressure - 47) $\mathrm{x} \mathrm{FiO}_{2}-\mathrm{PaCO}_{2} / \mathrm{R}$ - arterial blood oxygen partial pressure. The linear correlation coefficient was calculated to study the efficacy of gas exchange.

Extraction of cytoplasm and nuclear proteins. Lung tissue samples weighing $\sim 100 \mathrm{mg}$ were washed with $0.01 \mathrm{M}$ 
phosphate-buffered saline (PBS) supplemented with $1.5 \mathrm{ml}$ nuclear protein extract lysis buffer A (BioTeke Corporation, Beijing, China). Subsequently, the samples were placed on ice for 15-30 min and homogenized using an electric homogenizer following the addition of $0.5 \mathrm{ml}$ ice-cold NP-40 (10\%; BioVision, Inc., Milpitas, CA, USA). Then, the samples were vortexed for $10 \mathrm{sec}$ and centrifuged at $4^{\circ} \mathrm{C}$ and $12,000 \mathrm{x} \mathrm{g}$ for $30 \mathrm{sec}$; the supernatant produced was the cytoplasmic protein extract. The precipitate was washed once with cold PBS and then centrifuged at $4^{\circ} \mathrm{C}$ and $12,000 \times \mathrm{g}$ for $30 \mathrm{sec}$, after which the supernatant was discarded. Subsequently, $1.5 \mathrm{ml}$ join nucleoprotein extract lysis buffer B (BioTeke Corporation) was added and the samples were placed on ice for $30 \mathrm{~min}$, prior to centrifugation at $4^{\circ} \mathrm{C}$ and $12,000 \mathrm{x} \mathrm{g}$ for $2 \mathrm{~min}$ in order to produce the aspirate supernatant (nucleoprotein). Using the Bradford Protein Assay, the nuclear protein concentration was adjusted to $0.5-1.0 \mu \mathrm{g} / \mu \mathrm{l}$ and the samples were placed and stored at $-70^{\circ} \mathrm{C}$, according to a previous study (20).

Measurement of $N F-\kappa B$ protein expression by western blot analysis. The total protein quantity was analyzed using a Pierce BCA Protein Assay kit (\#23250; Thermo Fisher Scientific, Inc., Waltham, MA, USA). Equal quantities of total protein $(30 \mu \mathrm{g})$ were separated on a $10 \%$ Bis-Tris gel in NuPAGE MOPS SDS Running Buffer (all Invitrogen; Thermo Fisher Scientific, Inc.) and transferred to a polyvinylidene difluoride (PVDF) membrane (Immobilon; EMD Millipore, Billerica, MA, USA). The PVDF membrane was then blocked using 5\% skimmed milk in Tris-buffered saline (TBS; Tris-Cl, $50 \mathrm{mM}$; NaCl, $150 \mathrm{mM}$; pH 7.5; Thermo Fisher Scientific, Inc.) for $60 \mathrm{~min}$ at room temperature. Next, the membrane was incubated for $15 \mathrm{~h}$ at $4^{\circ} \mathrm{C}$ with mouse anti-pNF- $\kappa \mathrm{B}$ monoclonal antibody (1:200; cat. no. sc-166748; Santa Cruz Biotechnology, Inc., Dallas, TX, USA), rabbit anti-pNF- $\kappa$ B p65 polyclonal antibody (1:200; cat. no. ab16502; Abcam, Cambridge, UK) and mouse anti- $\beta$-actin monoclonal antibody (1:500; \#BA2305; Boster Systems, Inc., Pleasanton, CA, USA). The membrane was washed three times for 5 min each with $1 \mathrm{X}$ TBS containing 0.15 Tween-20, and then incubated for $1 \mathrm{~h}$ with horseradish peroxidase (HRP)-conjugated secondary antibodies (1:1,000; sc-2370; Santa Cruz Biotechnology, Inc.) at room temperature. The membrane was exposed to high performance autoradiography film (\#87897; Fuji XR film; Fujifilm Corporation, Tokyo, Japan) and visualized using enhanced chemiluminescence reagents and the ChemiScope 2850 Fluorescence/Chemiluminescence Imaging system (Clinx Science Instruments Co., Ltd., Shanghai, China).The integrated density value of the band intensities on the film was analyzed using ImageQuant version 5.2 software (Molecular Devices, Sunnyvale, CA, USA).

Evaluation of CINC mRNA expression level in lung tissue using reverse transcription-quantitative polymerase chain reaction $(R T-q P C R)$. RNA was isolated from lung tissue using TRIzol (Invitrogen; Thermo Fisher Scientific, Inc.) and quantified using a NanoDrop 2000/2000c (Thermo Fisher Scientific, Inc.). Subsequently, $1 \mu \mathrm{g}$ total RNA from each sample was denatured at $70^{\circ} \mathrm{C}$ for $10 \mathrm{~min}$ and chilled on ice for $10 \mathrm{~min}$. RT reactions were performed in a volume of
$20 \mu \mathrm{l}$ containing $4 \mu 1$ 5X RT buffer (Toyobo Co., Ltd., Osaka, Japan), $1 \mu$ l RT Enzyme Mix (Toyobo Co., Ltd.) and $1.0 \mu 1$ (5 pmol) of the sense and antisense primers (BGI, Shenzhen, China) in the presence of PCR buffer (Toyobo, Co., Ltd.). qPCR was performed in a volume of $20 \mu \mathrm{l}$ containing $2 \mu \mathrm{l}$ cDNA, $8 \mu \mathrm{l}$ forward and reverse primers $(10 \mathrm{pmol} / \mu \mathrm{l}, 10 \mu \mathrm{M})$ and $10 \mu \mathrm{l}$ QuantiTect SYBRs Green PCR kit (QIAGEN, Inc., Toronto, Canada), which consisted of DNA polymerase, deoxynucleotide mix, buffer, $\mathrm{MgCl}_{2}$ and fluorescent dyes. The gene-specific primer sequences were as follows: CINC forward, 5'-TATTGGGAGACCATTAGGTG-3' and reverse, 5'-CATAAA ATGTCCAAGGGAAG-3'; and GAPDH forward, 5'-GAACATCCAGAGTTTGAAGG-3' and reverse, 5'-TCGGTGCAATCTATCTTCTT-3'. The PCR protocol consisted of three stages: Denaturation, amplification and melting curve analysis for product identification. The denaturation and amplification conditions were $95^{\circ} \mathrm{C}$ for $20 \mathrm{~min}$, followed by 40 cycles of $30 \mathrm{sec}$ denaturation at $95^{\circ} \mathrm{C}, 10 \mathrm{sec}$ annealing at $60^{\circ} \mathrm{C}$ and $15 \mathrm{sec}$ elongation at $72^{\circ} \mathrm{C}$. The temperature transition rate was $20^{\circ} \mathrm{C} / \mathrm{sec}$, except when heating at $72^{\circ} \mathrm{C}$, when it was $5^{\circ} \mathrm{C} / \mathrm{sec}$. Fluorescence was measured at the end of every cycle to allow quantification of cDNA. Relative mRNA expression levels were calculated using the $2^{-\Delta \Delta C q}$ method (21). This value was then used to determine the relative amount of amplification in each sample by interpolating from a standard curve. The mRNA expression level of CINC was normalized to that of GAPDH. Nuclease-free water was used as a RT-minus control.

Immunohistochemical analysis NF- $\kappa B, C I N C$ and ENA-78 expression in lung tissue. The lobes of lungs from mice were dissected, fixed in $10 \%$ formaldehyde and processed in preparation for immunohistochemistry. Slides were dewaxed and rehydrated, and antigen retrieval was performed using $10 \mathrm{mM}$ sodium citrate $(\mathrm{pH}$ 6.1; Beyotime Institute of Biotechnology) and blocked using 5\% bovine serum albumin (Sigma-Aldrich) for $60 \mathrm{~min}$ at room temperature. Sections of lung tissue $(4 \mu \mathrm{m})$ were incubated with primary antibodies anti-NF-кB (1:300; Santa Cruz Biotechnology, Inc.), anti-CINC (1:300; Santa Cruz Biotechnology, Inc.) and anti-ENA-78 (1:200; Santa Cruz Biotechnology, Inc.) overnight at $4^{\circ} \mathrm{C}$ and then with polyclonal immunoglobulins/HRP (1:100; Beyotime Institute of Biotechnology) for $1 \mathrm{~h}$ at room temperature. Nuclei were counterstained with HE. Control samples were incubated with the same antibodies. Cover slips were mounted with $80 \%$ glycerol (Beijing Zhongshan Golden bridge Biotechnology, Co., Ltd., Beijing, China). Samples were examined under a microscope equipped with a digital camera (BX51 TRF; Olympus Corporation). ENA-78 positive areas were quantified by densitometry using Image-Pro Plus software 6.0 (Media Cybernetics, Inc., Rockville, MD, USA).

Measurement of leukocytes and proportion of PMNs in $B A L F$. A total of $0.5 \mathrm{ml} \mathrm{BALF}$ was collected and total cells and neutrophils were counted using a hemocytometer in a double-blind manner for the measurement of leukocytes and the proportion of PMNs.

Statistical analysis. The results are expressed as the mean \pm standard deviation. Statistical analyses consisted 
of a one-way analysis of variance and a Student's t-test was used to compare groups. $\mathrm{P}<0.05$ was considered to indicate a statistically significant difference. The statistical analysis was conducted using SPSS 19.0 software (IBM SPSS, Armonk, NY, USA).

\section{Results}

Animal phenotype. The mice in the control group were breathing easily and their lungs appeared pink upon dissection. In the ARDS mice, after $6 \mathrm{~h}$ induction with LPS, shortness of breath with oral cyanosis and blood-like liquid in the nose was observed. In addition, the lung volume was increased, the lungs were deep purple in appearance and flake bleeding was observed under the visceral pleura. In the PDTC + LPS group, the shortness of breath was attenuated and the lung was less inflamed and reddened. The scattered bleeding on the surface of the lung and the capsular tension was reduced on the lungs of mice in the PDTC + LPS group in comparison with the LPS group (Fig. 1).

Pathology of lung tissue determined by HE staining. In the control group, the structure of the lung tissue was normal and no inflammatory cells were detected. However, in the LPS group after 12 and $24 \mathrm{~h}$, the alveoli septum was thickened, the pulmonary interstitial was highly congested, the alveolar wall was fractured and a large number of infiltrative inflammatory cells were detected. In addition, as time progressed there was an increase in inflammatory cell infiltration and aggravated lung tissue damage. Similar symptoms were detected in the PDTC + LPS group; however, the lung tissue injury was milder compared with LPS group, as determined by HE staining (Fig. 2).

Effect of PDTC on $\mathrm{P}(\mathrm{A}-\mathrm{a}) \mathrm{O}_{2}$ in LPS-induced ARDS mice. $\mathrm{P}(\mathrm{A}-\mathrm{a}) \mathrm{O}_{2}$ was significantly higher in the LPS group in comparison with the control group at each time point $(\mathrm{P}<0.01$; Fig. 3). Following treatment with PDTC, the level of oxygenation improved in lung tissue as time progressed, and the $\mathrm{P}(\mathrm{A}-\mathrm{a}) \mathrm{O}_{2}$ gradually decreased in comparison with the LPS group $(\mathrm{P}<0.05)$. However, $\mathrm{P}(\mathrm{A}-\mathrm{a}) \mathrm{O}_{2}$ in the PDTC + LPS group was significantly higher compared with the control group (Fig. 3).

Differences in $p-N F-\kappa B$ and $N F-\kappa B$ P65 protein expression in the cytoplasm and nucleus in lung tissue. The expression levels of $\mathrm{p}-\mathrm{NF}-\kappa \mathrm{B}$ were significantly higher in the LPS group in comparison with the control group $(\mathrm{P}<0.01)$. However, $\mathrm{p}-\mathrm{NF}-\kappa \mathrm{B}$ protein expression in the lung tissue of the PDTC + LPS group was significantly reduced, as compared with the LPS group $(\mathrm{P}<0.05)$, although it remained increased, as compared with the control group. This suggests that PDTC can effectively inhibit the phosphorylation of NF- $\kappa \mathrm{B}$ (Fig. 4A and B). NF- $\kappa$ B P65 cytoplasmic protein expression was significantly lower in the LPS group in comparison with the control group $(\mathrm{P}<0.01)$; however, the production of $\mathrm{P} 65$ was significantly higher in the pulmonary nucleus of the LPS group in comparison with the control group $(\mathrm{P}<0.01$; Fig. 4C and D). P65 protein expression in the cytoplasm of lung tissue was significantly increased in the PDTC + LPS group in comparison with the LPS group $(\mathrm{P}<0.05)$, and the expression of P65 was significantly decreased in the nuclei of the PDTC+LPS group in comparison with the LPS group $(\mathrm{P}<0.01$; Fig. 4E and F).

CINC mRNA expression in lung tissue. The expression of CINC mRNA in lung tissue was significantly increased in the mice that received an i.p. injection of LPS in comparison with the control group $(\mathrm{P}<0.01)$, and continued to increase over time. In the PDTC + LPS group, CINC mRNA expression in lung tissue was significantly decreased in comparison with the LPS group $(\mathrm{P}<0.05$; Fig. 5).

Expression of $N F-\kappa B, C I N C$ and ENA-78 in lung tissue. The immunohistochemistry results demonstrated that the expression levels of NF- $\kappa \mathrm{B}, \mathrm{CINC}$ and ENA-78 were markedly increased in the lung tissue of LPS-induced ARDS mice. Cell morphological analysis revealed that the majority of cells in the LPS lung tissue were infiltrated PMNs and endothelial cells. However, in the control group, the expres-

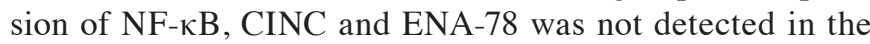
lung tissue of mice. The number of positive cells stained with NF- $\mathrm{B}, \mathrm{CINC}$ and ENA-78 in PDTC + LPS group was markedly decreased in comparison with the LPS group (Figs. 6-8).

Expression of $I L-8$ and $I L-10$ in serum and BALF. The expression levels of IL-8 and IL-10 in the serum and BALF from the LPS group was significantly increased, as compared with the control group $(\mathrm{P}<0.01)$. In the PDTC + LPS group, IL-8 expression was significantly decreased, as compared with the LPS group $(\mathrm{P}<0.05)$, whereas it was increased in comparison with the control group. Over the time period, however, the production of IL-10 in the serum and BALF from the LPS group was increased. In the PDTC + LPS group, the expression level of IL-10 was substantially higher than that in the control group, whereas it was significantly reduced in comparison with the LPS group ( $\mathrm{P}<0.05$; Fig. 9).

Number of leukocytes and proportion of PMNs in BALF. The total number of leukocytes was significantly increased in the LPS group, as compared with the control group $(\mathrm{P}<0.01)$. In the PDTC + LPS group, the number of leukocytes was significantly decreased, as compared with the LPS group $(\mathrm{P}<0.05)$ at each time point, but was significantly increased, as compared with the control group $(\mathrm{P}<0.05)$. The proportion of PMNs in BALF was significantly higher in the LPS and PDTC + LPS groups in comparison with the control group $(\mathrm{P}<0.01)$, but the proportion of PMNs was significantly reduced in the PDTC + LPS group in comparison with the LPS group $(\mathrm{P}<0.05$; Fig. 10).

\section{Discussion}

$\mathrm{NF}-\kappa \mathrm{B}$ is a target for anti-inflammatory ARDS treatment and serves an important role in initiating and developing inflammatory reactions $(16,22)$. The association between $\mathrm{NF}-\kappa \mathrm{B}$, cytokines and chemokines has become a topic of interest with regards to the pathogenesis of ARDS (12). The expression of inflammatory mediators can be downregulated by delaying the activation of the $N F-\kappa B$ signal pathway, 
A

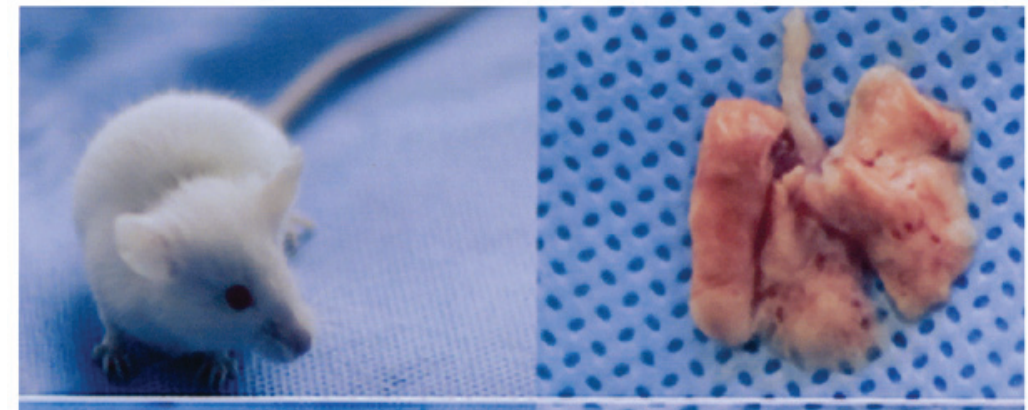

B

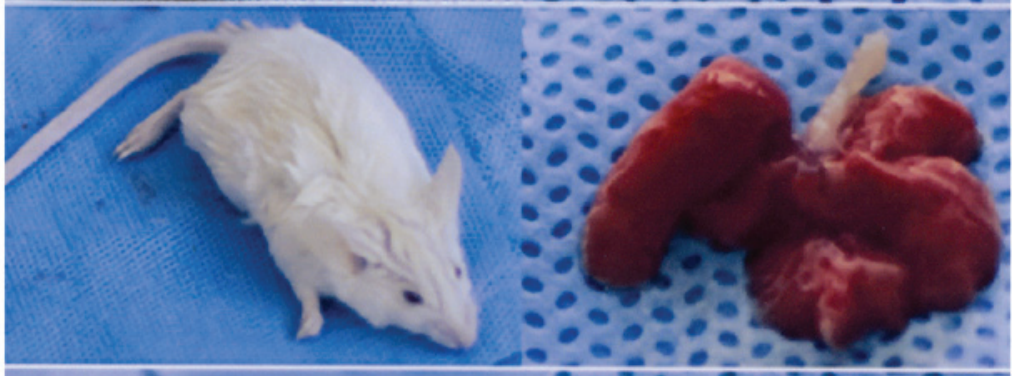

C

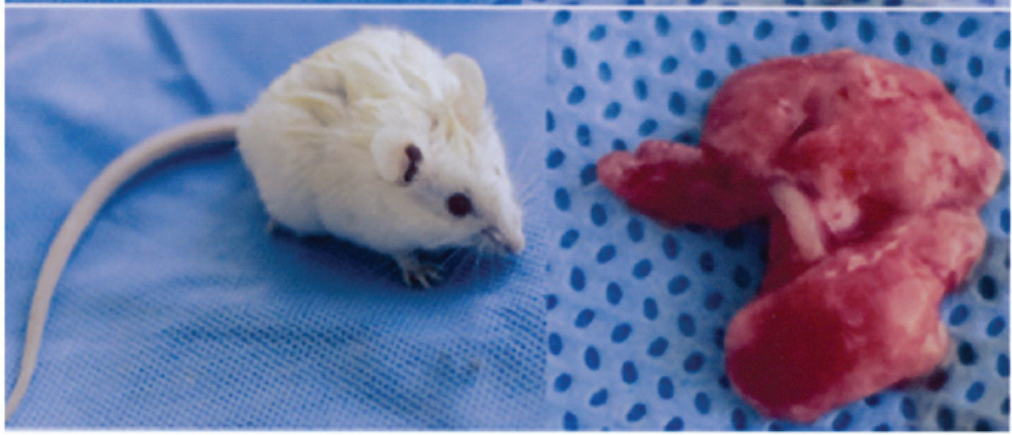

Figure 1. General condition (left panel) and lungs (right panel) of mice in the (A) normal saline control, (B) lipopolysaccharide (LPS) and (C) LPS + pyrrolidine dithiocarbamate (PDTC) group ( $\mathrm{n}=12)$. Mice were treated with $20 \mathrm{mg} / \mathrm{kg}$ LPS with PDTC $(0,40,120 \mathrm{or} 160 \mathrm{mg} / \mathrm{kg}$, intraperitoneally).

A

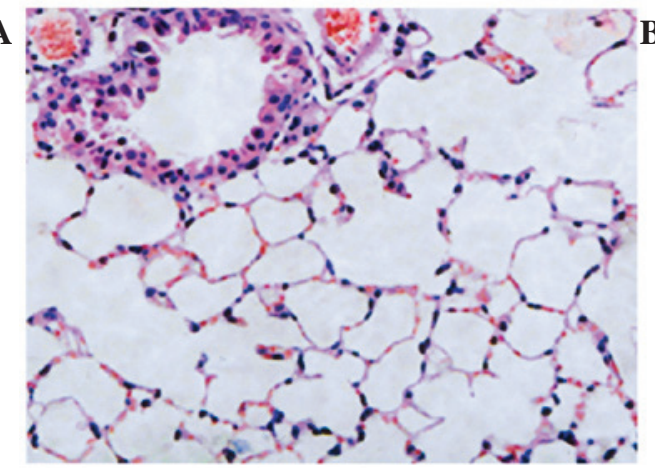

C

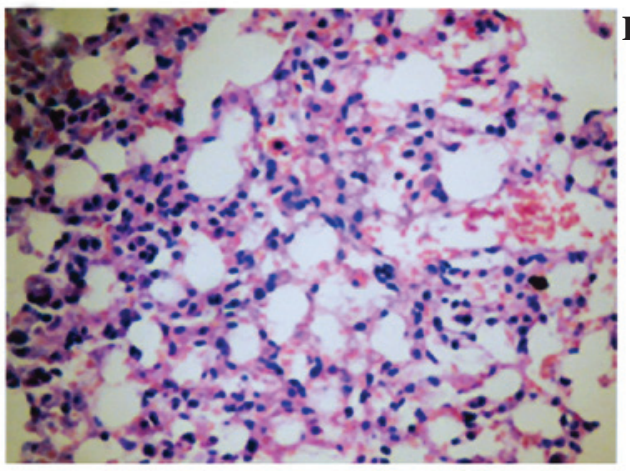

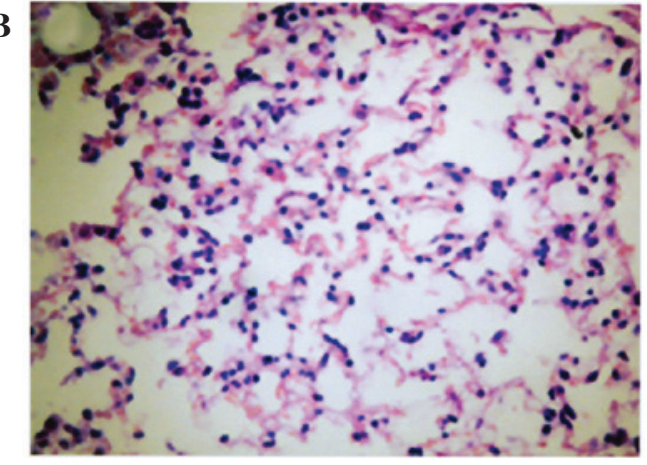

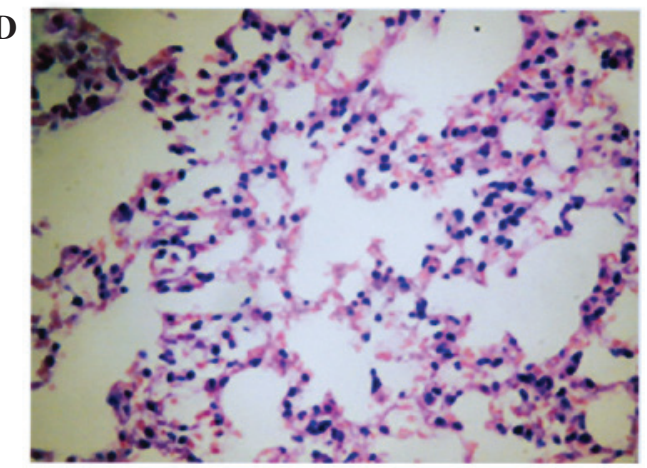

Figure 2. Effect of pyrrolidine dithiocarbamate (PDTC) on lung histopathological changes of mice at 12 and $24 \mathrm{~h}$ following intraperitoneal injection with saline, and lipopolysaccharide (LPS) with or without PDTC (stain, hematoxylin and eosin; magnification, $\mathrm{x} 400$ ). (A) Normal saline group with integrated lung tissue and no inflammatory cells; (B) LPS group at $12 \mathrm{~h}$; (C) LPS group at $24 \mathrm{~h}$ with widened lung intervals, highly congested pulmonary interstitia, fractured alveolar walls and numerous infiltrative inflammatory cells; and (D) PDTC + LPS group with milder lung tissue injury in comparison with the LPS group. 
thereby suppressing PMN accumulation in the lungs, effectively repressing the excessive activation of the inflammatory response and reducing the damage inflicted on lung tissue (23).

A previous study observed that the activation of NF- $\kappa \mathrm{B}$ in ARDS could increase the production of inflammatory cytokines, including adhesion molecules (such as CD11b/CD18, ICAM-1), chemokines (such as IL-8), TNF- $\alpha$ and IL-1 involving a number of downstream gene transcriptions (5). $\mathrm{NF}-\kappa \mathrm{B}$ was demonstrated to be a central transcription factor that promotes the production of cytokines, adhesion molecules and chemokines by specifically binding to $\kappa \mathrm{B}$ promoters in the nucleus $(24,25)$. The P50/P65 NF- $\kappa \mathrm{B}$ heterodimer serves a primary physiological function during inflammation $(12,13)$. As the principal subunit, NF-кB P65 exists in an inactive dimer form in the cytoplasm and directly combines with the inhibitory protein I $\mathrm{KB}$ to form a trimeric complex $(26,27)$. Previous studies have demonstrated that when NF- $\kappa$ B is excessively activated, IL- 8 and TNF- $\alpha$ are overexpressed, whereas the expression of IL-10 is decreased, in ARDS (20). An imbalance of the inflammatory response is the principal feature in ARDS $(28,29)$. Therefore, inhibiting the activation of the NF- $\mathrm{KB}$ signal pathway and reducing the expression of inflammatory cytokines and chemokines may inhibit the inflammatory response at the source, leading to novel strategies in treating ARDS.

In the present study, the widened lung interval, highly congested pulmonary interstitial, fractured alveolar wall and increased infiltrative inflammatory cell in the LPS group aggravated lung tissue damage, gradually increased $\mathrm{P}(\mathrm{A}-\mathrm{a}) \mathrm{O}_{2}$ and resulted in oxygenation obstacles over time. In addition, the results of the NF- $\kappa B$ western blot demonstrated that $\mathrm{p}-\mathrm{NF}-\kappa \mathrm{B}$ protein expression was significantly increased in the lung cells of the ARDS mice at each time point in comparison with the control group. The expression of the P65 protein in the nucleus was significantly enhanced, suggesting that NF- $\kappa \mathrm{B}$ may be activated by phosphorylation and degradation. These results are consistent with previous studies (20).

IL-8, a proinflammatory cytokine, is a promoter for ARDS and serves a crucial role in the course of PMN migration from circulating blood to sites of inflammation (30). In patients with ARDS, the body can prevent excessive activation of the inflammatory response by activating an anti-inflammatory response and releasing anti-inflammatory cytokines, such as IL-10, in order to attenuate the extent of tissue damage (31). IL-10 is a crucial anti-inflammatory cytokine in the immune response and can inhibit the production of IL- 8 and TNF- $\alpha$ in monocytes and macrophages, and repair injured tissue by regulating the immune response; however, overexpression can aggravate the immune response $(17,32)$. Previous studies demonstrated that the genes of cytokines such as IL-8 and IL-10 encode the binding site for NF-אB (20), and that LPS-activated NF- $\kappa \mathrm{B}$ binds to these genes, resulting in their expression $(5,33)$. In the present study, it was observed that the production of IL- 8 was rapidly increased after $2 \mathrm{~h}$ in the serum and BALF of ARDS mice; however, the expression of IL-10 was not significantly increased during the first $6 \mathrm{~h}$ following injection of LPS. This indicates that there is an imbalance of proinflammatory and anti-inflammatory

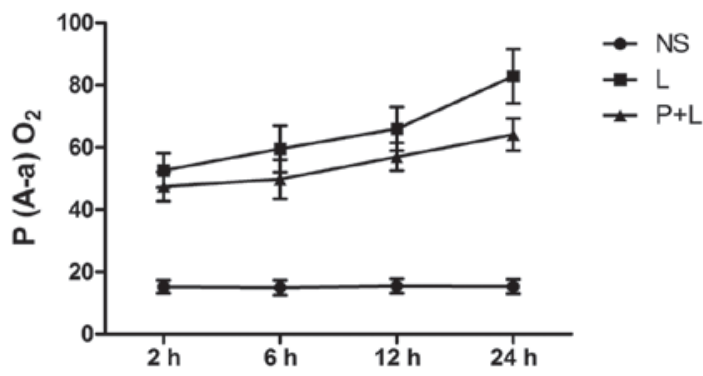

Figure 3. Effect of $\mathrm{P}$ on $\mathrm{P}(\mathrm{A}-\mathrm{a}) \mathrm{O}_{2}$ in the saline, $\mathrm{L}$ and $\mathrm{P}+\mathrm{L}$ group $\mathrm{P}(120 \mathrm{mg} / \mathrm{kg}$, intraperitoneally) was administered $30 \mathrm{~min}$ prior to $\mathrm{L}$ administration $(20 \mathrm{mg} / \mathrm{kg}$ intraperitoneally). Mice were anesthetized at 2, 6, 12 and $24 \mathrm{~h}$ following treatement with NS or L. Blood was collected immediately in order to determine $\mathrm{P}(\mathrm{A}-\mathrm{a}) \mathrm{O}_{2}$. NS, normal saline; $\mathrm{P}(\mathrm{A}-\mathrm{a}) \mathrm{O}_{2}$, oxygen partial pressure difference between alveolar and arterial; $\mathrm{P}$, pyrrolidine dithiocarbamate; L, lipopolysaccharide.

molecules during the early stage of ARDS. Although the level of IL-8 and IL-10 were increased simultaneously over time, the pro- and anti-inflammatory cytokines were imbalanced, and a large number of proinflammatory cytokines released from inflammatory cells further aggravated lung tissue damage. Thus, a cascade of inflammatory responses commenced.

The results from the current study demonstrated that chemokines (in particular IL-8, ENA-78 and CINC) released by damaged cells in ARDS stimulated PMN extravasation and their migration to sites of inflammation. CINC, a member of the IL-8 family, is a specific PMN chemokine (11). CINC-1 and -3 serve important roles in PMN recruitment to the lung in ARDS induced by LPS (10). The enhanced expression of CINC mRNA and protein inhibits PMN apoptosis and activates a large number of PMNs, causing them to accumulate in the lung and result in lung injury (11). Endogenous TNF- $\alpha$ is associated with the increased expression of ENA-78. ENA-78, a member of CXC chemokine superfamily, can activate PMNs, induce secretion of numerous cytokines in PMNs and aggravate inflammation (19). In the present study, the results demonstrated that the expression of CINC mRNA was higher than that in the control group, and the immunohistochemical results demonstrated that there were a large number of positive immunoreactive cells with CINC and ENA-78 in the cytoplasm of macrophages and pulmonary interstitial cells. The number of leukocytes and PMNs in BALF were increased in comparison to the control group, which indicated that the high expression of chemokines (CINC and ENA-78) is closely related to the accumulation of PMNs.

As a dithiocarbamate of the pyrrole derivatives, PDTC can inhibit the activation of NF- $\kappa \mathrm{B}$ by hindering the

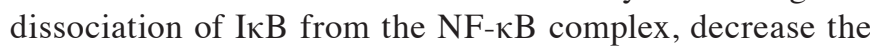
production of CINC and ENA-78, and prevent the aggregation of PMNs in the lung tissue of ARDS $(18,34)$. The results from the present study suggest that PDTC can attenuate the mRNA expression of p-NF- $\mathrm{BB}, \mathrm{CINC}$ and ENA-78 by inhibiting the activation of $\mathrm{NF}-\mathrm{\kappa B}$, reducing the expression of IL-8 and IL-10, and inhibiting the activation of PMNs in BALF. Pretreatment with PDTC may have partially reduced lethality in LPS-induced mice and attenuated lung tissue 

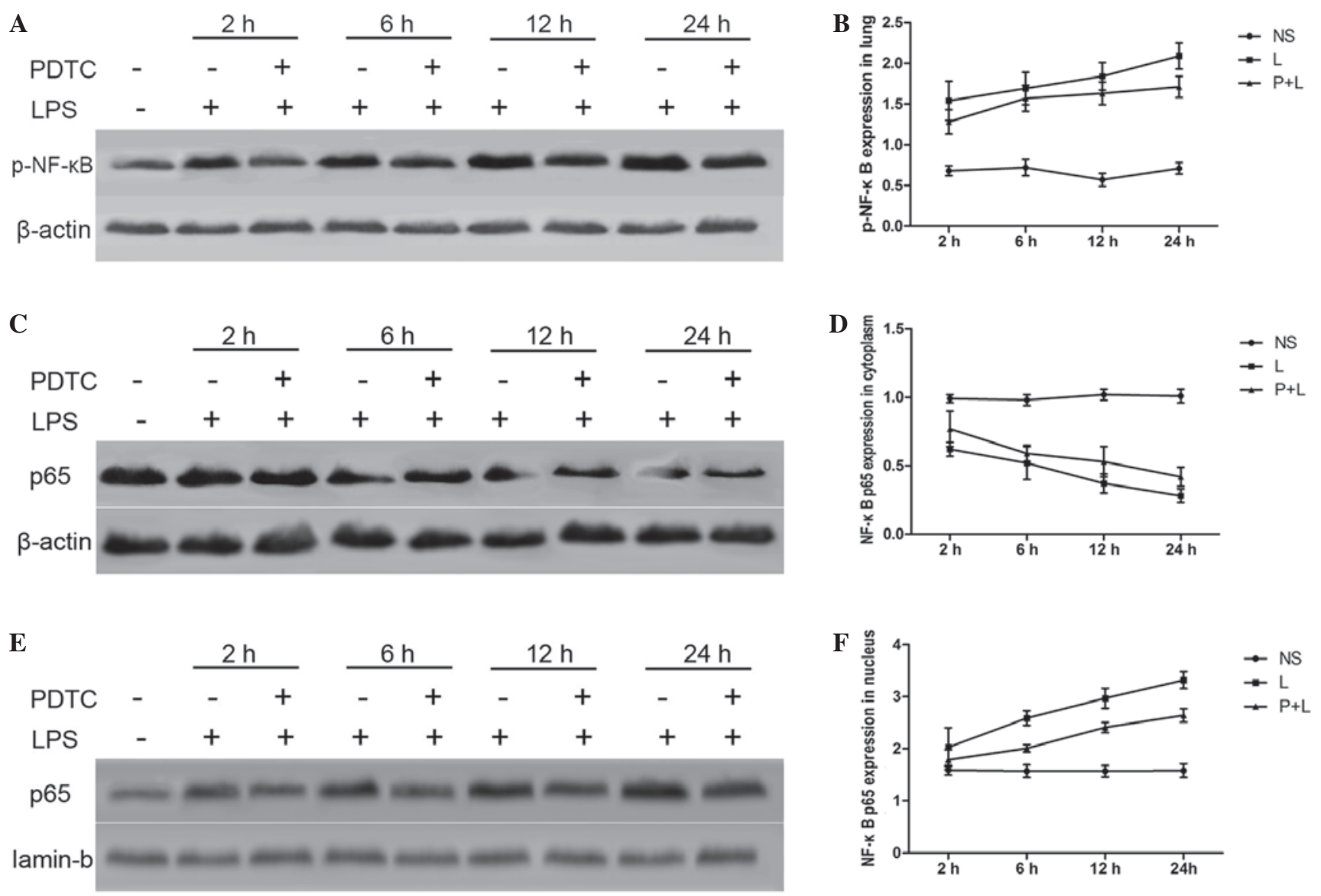

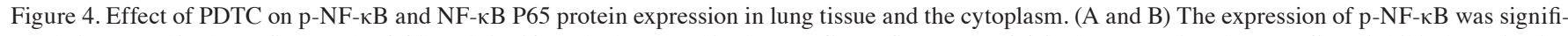
cantly increased in the LPS group $(\mathrm{P}<0.01)$ and significantly decreased in the PDTC + LPS group $(\mathrm{P}<0.05)$, demonstrating that PDTC can inhibit the activation of NF-kB. (C and D) NF-kB P65 protein expression was reduced in the cytoplasm of the LPS group ( $<<0.01)$; the production of P65 was significantly increased in nuclei of the LPS group in comparison with the NS group $(\mathrm{P}<0.01)$. ( $\mathrm{E}$ and $\mathrm{F}) \mathrm{P} 65$ expression was significantly increased in the cytoplasm $(\mathrm{P}<0.05)$, and significantly decreased in the nucleus, of the PDTC + LPS group in comparison with the LPS group $(\mathrm{P}<0.01)$. PDTC, pyrrolidine dithiocarbamate; NF- $\mathrm{kB}$, nuclear

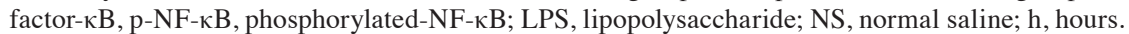
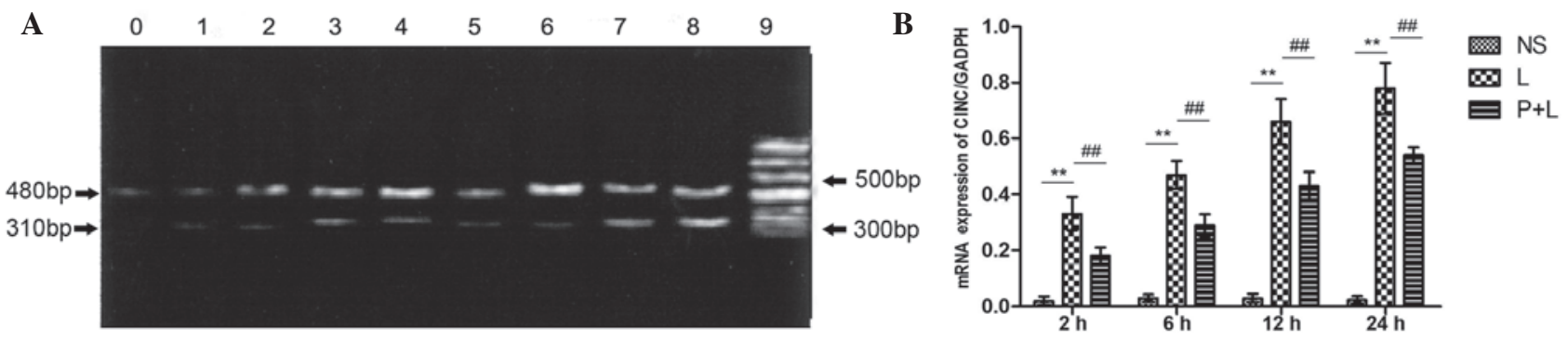

Figure 5. Change of CINC mRNA expression in lung tissue detected by qPCR. (A) CINC expression was detected by RT-PCR. (B) mRNA expression of CINC was detected by qPCR. ${ }^{* *} \mathrm{P}<0.01$ vs. NS group; ${ }^{\# \#} \mathrm{P}<0.01$ vs. L group. CINC, cytokine-induced neutrophil chemoattractant; NS, normal saline; L, lipopolysaccharide; $\mathrm{P}$, pyrrolidine dithiocarbamate; qPCR, quantitative polymerase chain reaction.

edema, damage, the production of inflammatory cytokines and chemokines, the infiltration of PMNs in the lung and pulmonary capillary permeability. This suggests that the $\mathrm{NF}-\mathrm{\kappa B}$ signaling pathway may become an important target in regulating ARDS in the lung, and that it may be useful in investigating the pathogenesis of ARDS and exploring more effective and targeted clinical therapies.

In conclusion, in the lung tissue of mice with ARDS induced by LPS, the degradation of NF- $\mathrm{B}$ was activated by phosphorylation and NF- $\mathrm{NB}$ p 65 migration from the cytoplasm to the nucleus. This was followed by NF- $\mathrm{kB}$ activation that commenced the synthesis and release of CINC and ENA-78, and resulted in the imbalanced expression of proinflammatory and anti-inflammatory cytokines, such as IL-8 and IL-10. These cytokines then stimulated the extravasation of PMNs and their direct migration to sites of inflammation, and resulted in a widened lung interval, highly congested pulmonary interstitial, fractured alveolar wall, increased inflammatory cell infiltration, the $\mathrm{P}(\mathrm{A}-\mathrm{a}) \mathrm{O}_{2}$ and oxygenation obstacles. Therefore, it can be hypothesized that 
A

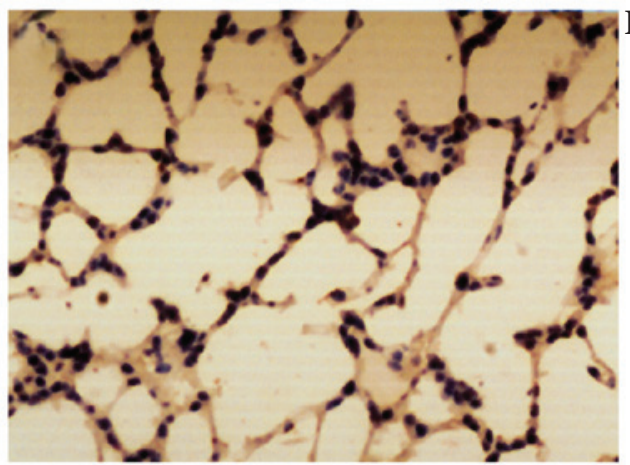

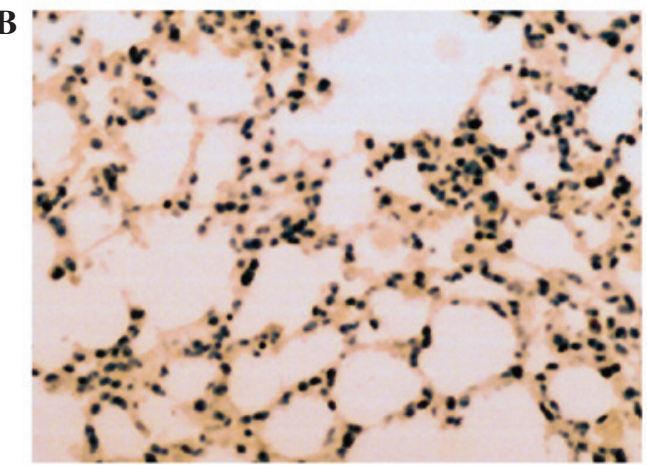

$\mathbf{C}$
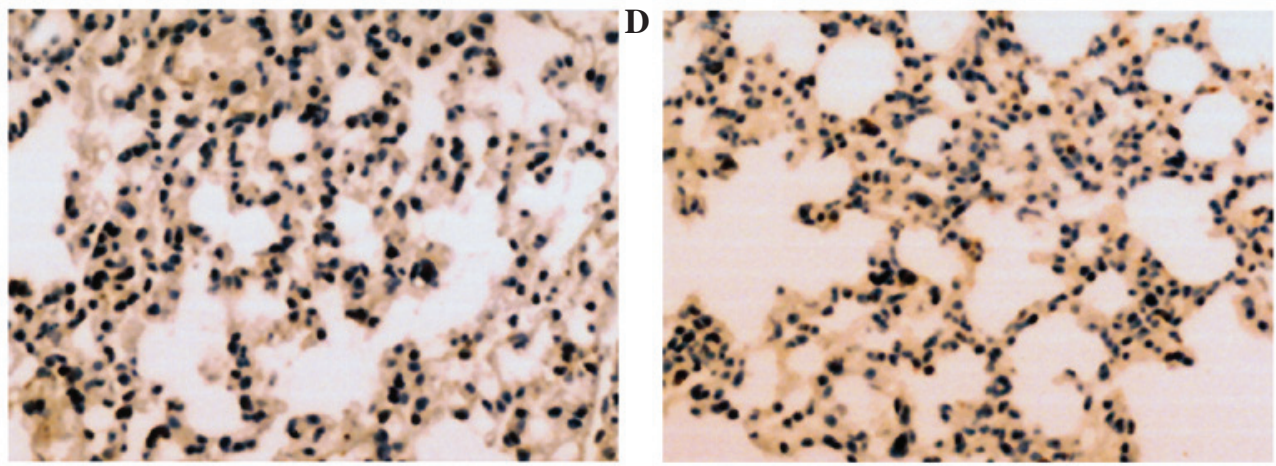

Figure 6. Expression of nuclear factor (NF)- $\kappa \mathrm{B}$ in lung tissue determined by immunohistochemistry (stain, hematoxylin and eosin; magnification, $\mathrm{x} 400$ ). (A) In the normal saline group, the positive NF- $\kappa \mathrm{B}$ cells were not observed; (B) in the $2 \mathrm{~h}$ lipopolysaccharide (LPS) group, low expression levels of NF- $\mathrm{B}$ were detected; (C) in the $12 \mathrm{~h}$ LPS group, the appearance of NF- $\mathrm{B}$ positive cells was enhanced in comparison with the $2 \mathrm{~h}$ LPS group; and (D) in the $12 \mathrm{~h}$ pyrrolidine dithiocarbamate + LPS group, NF- $\kappa$ B expression was reduced in comparison with the $12 \mathrm{~h}$ LPS group.

A

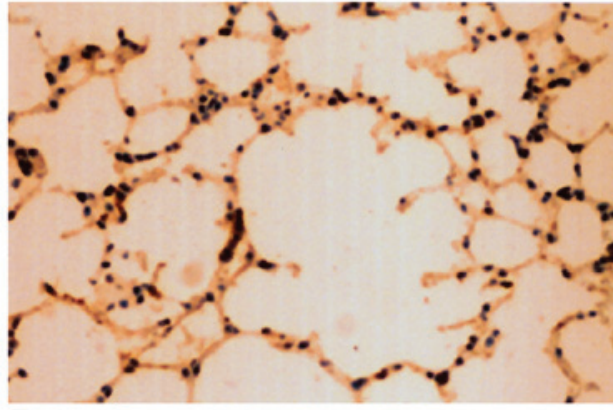

$\mathbf{C}$

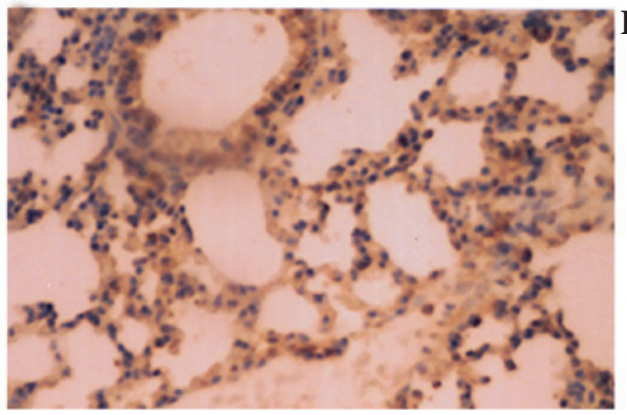

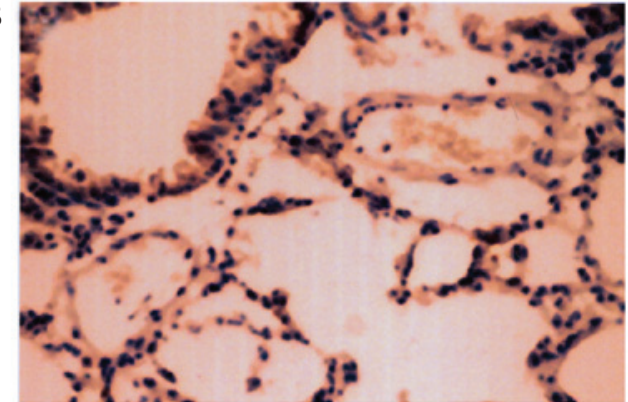

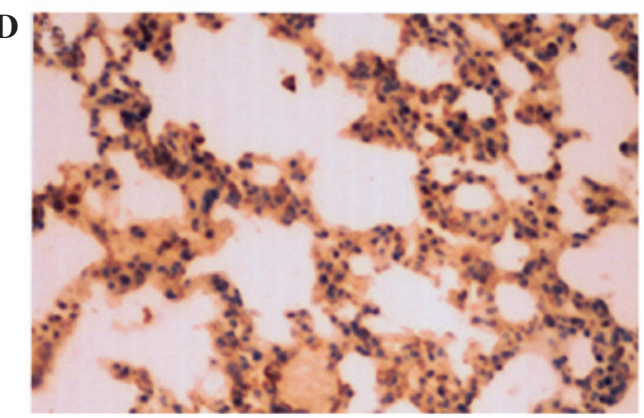

Figure 7. Cytokine-induced neutrophil chemoattractant (CINC) expression in the lung tissue of mice detected by immunohistochemistry (stain, hematoxylin and eosin; magnification, x400). (A) Normal saline group, (B) $2 \mathrm{~h}$ lipopolysaccharide (LPS) group, (C) 12 h LPS group and (D) 12 h pyrrolidine dithiocarbamate (PDTC) + LPS group. The expression of CINC was aggravatingly expressed in lung tissue of mice with LPS-induced acute respiratory distress syndrome. The number of positive cells stained with CINC in the PDTC + LPS group was markedly decreased in comparison with the $12 \mathrm{~h}$ LPS group.

PDTC, a specific inhibitor of $\mathrm{NF}-\kappa \mathrm{B}$, can reduce the release of chemokines and cytokines via the $\mathrm{NF}-\kappa \mathrm{B}$ signal pathway, thereby decreasing PMN accumulation in lung tissue, lung tissue damage and improved oxygenation. These results indicate that strategies to regulate the expression of chemokines, cytokines and the NF- $\mathrm{B}$ signal pathway in ARDS should focus on restricting the duration of PMN infiltration and the subsequent effects at inflammatory sites in ARDS. 


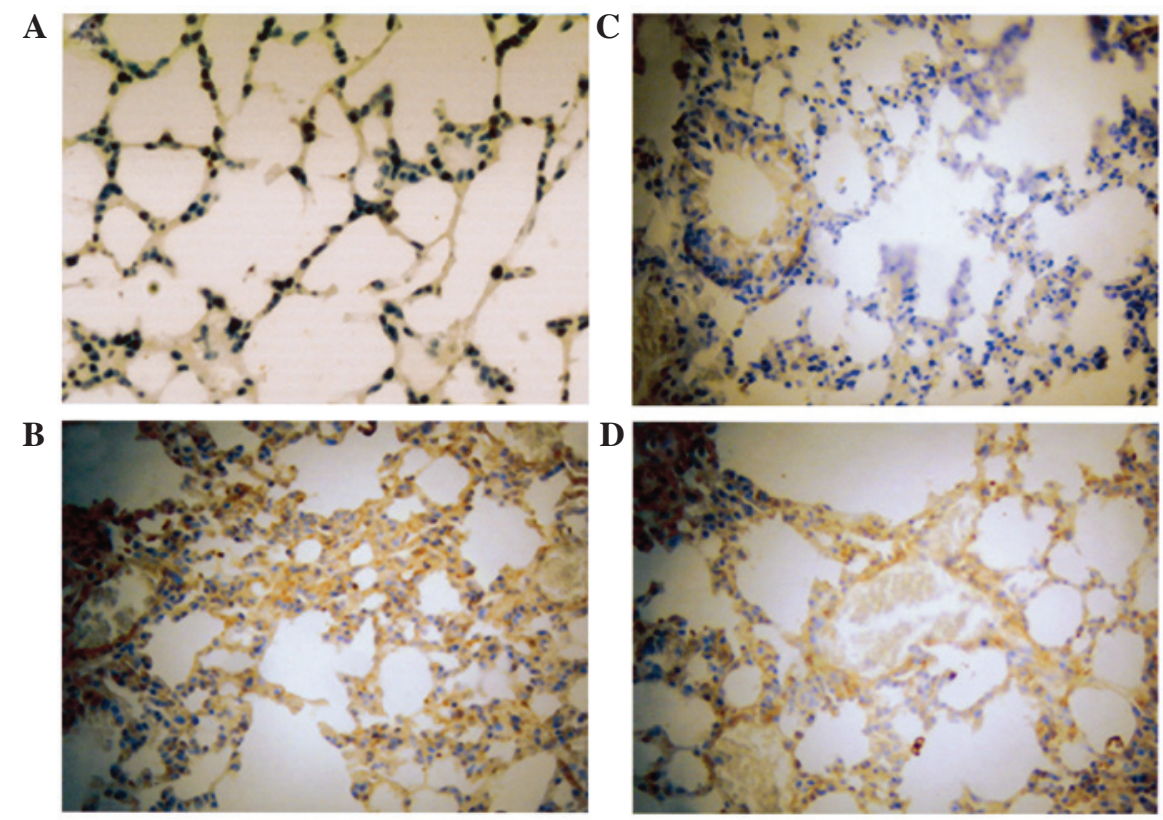

Figure 8. Expression of epithelial-derived neutrophil-activating protein 78 (ENA-78) in lung tissue, detected using immunohistochemstry (stain, hematoxylin and eosin; magnification, x400). (A) Normal saline (NS), (B) $2 \mathrm{~h}$ lipopolysaccharide (LPS), (C) $12 \mathrm{~h}$ LPS and (D) $12 \mathrm{~h}$ pyrrolidine dithiocarbamate + LPS group. No ENA-78 positive cells were detected in the NS group. ENA-78 expression was increased in the PDTC + LPS group at $12 \mathrm{~h}$, as compared with the NS group, and decreased in comparison with the LPS group.

A

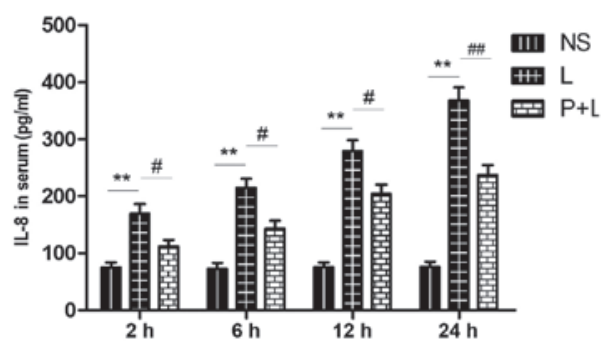

C

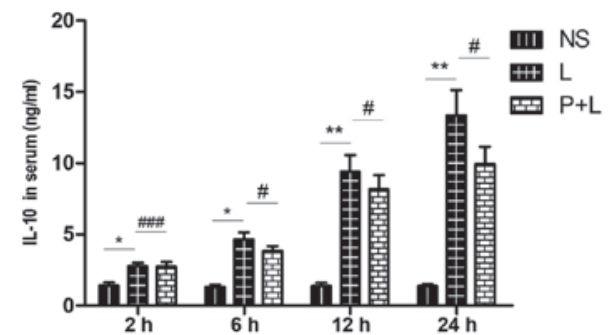

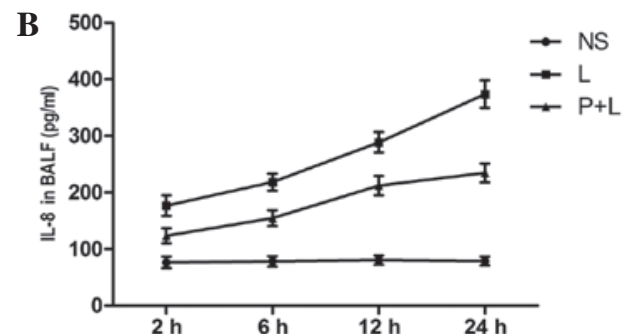

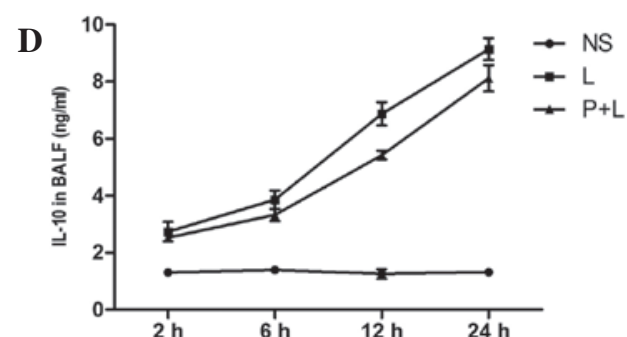

Figure 9. Expression of IL-8 in (A) serum and (B) BALF, and the expression of IL-10 in (C) serum and (D) BALF. "P<0.05, * $\mathrm{P}<0.01$ vs. the NS group; ${ }^{\#} \mathrm{P}<0.05,{ }^{\# \#} \mathrm{P}<0.01,{ }^{\# \# \#} \mathrm{P}>0.05$ vs. the L group. IL-8, interleukin-8; BALF, bronchoalveolar lavage fluid; NS, normal saline; L, lipopolysaccharide; $\mathrm{P}$, pyrrolidine dithiocarbamate.
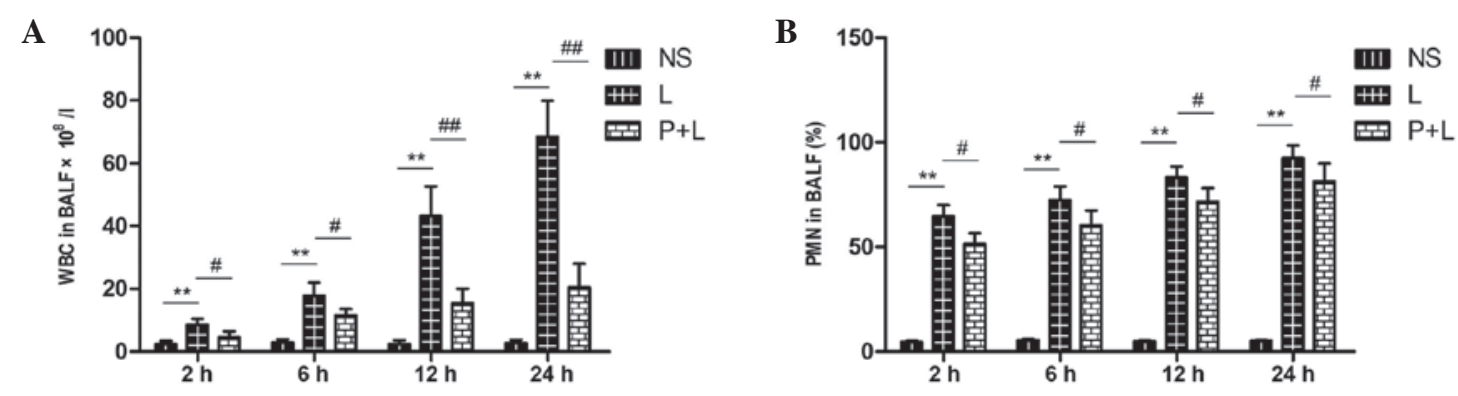

Figure 10. Number of (A) leukocytes and the proportion of (B) PMNs in the BALF of different groups. ${ }^{* *} \mathrm{P}<0.01$ vs. the NS group; ${ }^{~} \mathrm{P}<0.05$, ${ }^{\# \#} \mathrm{P}<0.01$ vs. the L group. PMN, polymorphonuclear; BALF, bronchoalveolar lavage fluid; NS, normal saline; L, lipopolysaccharide; P, pyrrolidine dithiocarbamate; WBC, white blood cell. 


\section{Acknowledgements}

The present study was supported by the Project of Science and Technology Department of Liaoning Province (grant no. 2013225305).

\section{References}

1. Ware LB and Matthay MA: The acute respiratory distress syndrome. N Engl J Med 342: 1334-1349, 2000.

2. Malhotra A: Low-tidal-volume ventilation in the acute respiratory distress syndrome. N Engl J Med 357: 1113-1120, 2007.

3. Meliton AY, Muñoz NM, Meliton LN, Binder DC, Osan CM, Zhu X, Dudek SM and Leff AR: Cytosolic group IVa phospholipase A2 mediates IL-8/CXCL8-induced transmigration of human polymorphonuclear leukocytes in vitro. J Inflamm (Lond) 7: 14, 2010.

4. Williams AE and Chambers RC: The mercurial nature of neutrophils: Still an enigma in ARDS? Am J Physiol Lung Cell Mol Physiol 306: L217-L230, 2014.

5. Bhatia M and Moochhala S: Role of inflammatory mediators in the pathophysiology of acute respiratory distress syndrome. J Pathol 202: 145-156, 2004.

6. Giebelen IA, van Westerloo DJ, LaRosa GJ, de Vos AF and van der Poll T: Local stimulation of alpha7 cholinergic receptors inhibits LPS-induced TNF-alpha release in the mouse lung. Shock 28: 700-703, 2007.

7. Nakayama S, Mukae H, Ishii H, Kakugawa T, Sugiyama K, Sakamoto N, Fujii T, Kadota J and Kohno S: Comparison of BALF concentrations of ENA-78 and IP10 in patients with idiopathic pulmonary fibrosis and nonspecific interstitial pneumonia. Respir Med 99: 1145-1151, 2005.

8. Marcus BC, Wyble CW, Hynes KL and Gewertz BL: Cytokine-induced increases in endothelial permeability after adhesion molecule expression. Surg. 2006; 120.

9. Nooteboom A, van der Linden CJ and Hendriks T: Modulation of adhesion molecule expression on endothelial cells after induction by lipopolysaccharide-stimulated whole blood. Scand J Immunol 59: 440-448, 2004.

10. Guo YL, Huang H, Zeng DX, Zhao JP, Fang HJ and Lavoie JP: Interleukin (IL)-4 induces production of cytokine-induced neutrophil chemoattractants (CINCs) and intercellular adhesion molecule (ICAM)-1 in lungs of asthmatic rats. J Huazhong Univ Sci Technol 33: 470-478, 2013.

11. Ulich TR, Howard SC, Remick DG, Wittwer A, Yi ES, Yin S, Guo K, Welply JK and Williams JH: Intratracheal administration of endotoxin and cytokines. VI. Antiserum to CINC inhibits acute inflammation. Am J Physiol 268 (2 Pt 1): L245-L250, 1995.

12. Lawrence T: The nuclear factor NF-kappaB pathway in inflammation. Cold Spring Harb Perspect Biol 1: a001651, 2009.

13. May MJ and Ghosh S: Signal transduction through NF-kappa B. Immunol Today 19: 80-88, 1998.

14. Lawrence T, Gillroy DW, Colville-Nash PR and Willoughby DA: Possible new role for NF-kappaB in the resolution of inflammation. Nat Med 7: 1291-1297, 2001

15. Kupfner JG, Arcaroli JJ, Yum HK, Nadler SG, Yang KY and Abraham E: Role of NF-kappaB in endotoxemia-induced alterations of lung neutrophil apoptosis. J Immunol 167: 7044-7051, 2001.

16. DeDiego ML, Nieto-Torres JL, Regla-Nava JA, Jimenez-Guardeño JM, Fernandez-Delgado R, Fett C, Castaño-Rodriguez C, Perlman S and Enjuanes L: Inhibition of NF-kB-mediated inflammation in severe acute respiratory syndrome coronavirus-infected mice increases survival. J Virol 88: 913-924, 2014.
17. Németh ZH, Haskó G and Vizi ES: Pyrrolidine dithiocarbamate augments IL-10, inhibits TNF-alpha, MIP-1alpha, IL-12, and nitric oxide production and protects from the lethal effect of endotoxin. Shock 10: 49-53, 1998.

18. Eren G, Cukurova Z, Hergunsel O, Demir G, Kucur M, Uslu E, Dalo E, Uhri M and Tugcu V: Protective effect of the nuclear factor kappa B inhibitor pyrrolidine dithiocarbamate in lung injury in rats with streptozotocin-induced diabetes. Respiration 79: 402-410, 2010.

19. Keane MP, Belperio JA, Burdick MD, Lynch JP, Fishbein MC and Strieter RM: ENA-78 is an important angiogenic factor in idiopathic pulmonary fibrosis. Am J Respir Crit Care Med 164: 2239-2242, 2001.

20. Wang H, Xu L, Zhao J, Wang D, Guo R, Wang J, Gong W, Liu T, Zhang Y and Dong L: Regulatory mechanism of pyrrolidine dithiocarbamate is mediated by nuclear factor- $\kappa \mathrm{B}$ and inhibits neutrophil accumulation in ARDS mice. Exp Ther Med 8: 614-622, 2014

21. Livak KJ and Schmittgen TD: Analysis of relative gene expression data using real-time quantitative PCR and the 2- $\Delta \Delta \mathrm{Ct}$ method. Methods 25: 402-408, 2001.

22. Christman JW, Lancaster LH and Blackwell TS: Nuclear factor kappa B: A pivotal role in the systemic inflammatory response syndrome and new target for therapy. Intensive Care Med 24: 1131-1138, 1998

23. Chen X, Yang X, Liu T, Guan M, Feng X, Dong W, Chu X, Liu J, Tian X, Ci X, et al: Kaempferol regulates MAPKs and $\mathrm{NF}-\kappa \mathrm{B}$ signaling pathways to attenuate LPS-induced acute lung injury in mice. Int Immunopharmacol 4: 209-216, 2012.

24. Kang JL, Lee HW, Lee HS, Pack IS, Chong Y, Castranova V and Koh Y: Genistein prevents nuclear factor-kappa B activation and acute lung injury induced by lipopolysaccharide. Am J Resp Crit Care Med 164: 2206-2212, 2001.

25. Chignard $M$ and Balloy V: Neutrophil recruitment and increased permeability during acute lung injury induced by lipopolysaccharide. Am J Physiol Lung Cell Mol Physiol 279: L1083-L1090, 2000.

26. Rahman A and Fazal F: Blocking NF- $\mathrm{BB}$ : An inflammatory issue. Proc Am Thorac Soc 8: 497-503, 2011.

27. Leverence JT, Medhora M, Konduri GG and Sampath V: Lipopolysaccharide-induced cytokine expression in alveolar epithelial cells: Role of $\mathrm{PKC} \zeta$-mediated p47phox phosphorylation. Chem Biol Interact 189: 72-81, 2011.

28. Park WY, Goodman RB, Steinberg KP, Ruzinski JT, Radella F II, Park DR, Pugin J, Skerrett SJ, Hudson LD and Martin TR: Cytokine balance in the lungs of patients with acute respiratory distress syndrome. Am J Respir Crit Care Med 164 (10 Pt 1): 1894-1903, 2001.

29. Suratt BT and Parsons PE: Mechanisms of acute lung injury/acute respiratory distress syndrome. Clin Chest Med 27: 579-589; abstract viii, 2006.

30. Kunkel SL, Standiford T, Kasahara K and Strieter RM: Interleukin-8 (IL-8): The major neutrophil chemotactic factor in the lung. Exp Lung Res 17: 17-23, 1991.

31. Shen Y, Wang D and Wang X: Role of CCR 2 and IL-8 in acute lung injury: A new mechanism and therapeutic target. Expert Rev Respir Med 5: 107-114, 2011.

32. Foulds KE, Rotte MJ and Seder RA: IL-10 is required for optimal CD8 T cell memory following Listeria monocytogenes infection. J Immunol 177: 2565-2574, 2006.

33. Lin $\mathrm{CH}$, Cheng $\mathrm{HW}$, Ma HP, Wu CH, Hong $\mathrm{CY}$ and Chen $\mathrm{BC}$ : Thrombin induces NF-kappaB activation and IL-8/CXCL8 expression in lung epithelial cells by a Racl-dependent PI3K/Akt pathway. J Biol Chem 286: 10483-10494, 2011.

34. Lauzurica P, Martínez-Martínez S, Marazuela M, Gómez del Arco P, Martínez C, Sánchez-Madrid F and Redondo JM: Pyrrolidine dithiocarbamate protects mice from lethal shock induced by LPS or TNF- $\alpha$. Eur J Immunol 29: 1890-1900, 1999. 